\title{
The covenantal trinitarian alternative to the scholastic dilemma
}

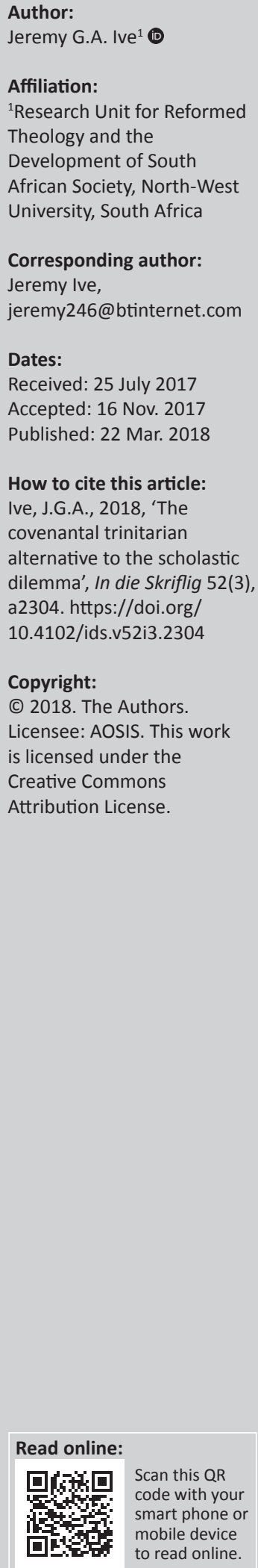

This article sets out what it calls the 'scholastic dilemma' about whether God's relation to the world is necessary or contingent - the former is based on a view of God primarily as intellect and the latter on a view of God primarily as will. In his dictum, Deus legibus solutus est sed non exlex, John Calvin rejects both these positions. The trinitarian basis for this dictum was spelt out more fully by later Calvinistic thinkers, including Abraham Kuyper and Cornelius van Til. Implicitly for Calvin and explicitly for Kuyper and Van Til, the love of the Persons of the Trinity for one another is the basis for God's covenantal trustworthiness in his dealings with the world. Recognising this trinitarian basis allows us to conceive of God as at once faithful in his dealing with the world, and yet not dependent on the world for his existence. This has profound and far-reaching implications for our understanding of society, including the universal and institutional church and a recognition of the priority of relationships, both theoretically and practically.

\section{The covenantal trinitarian alternative to the scholastic dilemma}

This article is offered as a preliminary 'pre-theoretical' groundwork for systematic Christian thinking. It seeks to describe the 'scholastic dilemma', that is the irresolvable question about whether God's relation to the world is necessary or contingent. One horn of the dilemma derives from the view of God primarily as intellect. The other horn of the dilemma derives from the view of God primarily as will. In his dictum, Deus legibus solutus est sed non exlex, John Calvin rejects both these positions. The trinitarian basis for this dictum was spelt out more fully by later Calvinistic thinkers, including Abraham Kuyper and Cornelius van Til. Implicitly for Calvin and explicitly for Kuyper and Van Til, the love of the Persons of the Trinity for one another is the basis for God's covenantal trustworthiness in his dealings with the world. Recognising this trinitarian basis allows us to conceive of God as at once faithful in his dealing with the world, and yet not dependent on the world for his existence. This has profound and far-reaching implications for our understanding of society, including the universal and institutional church, with a recognition of the priority of relationships.

\section{Introduction}

The discussion below sets out in outline how a trinitarian approach provides a genuine alternative to scholastic philosophy. The latter is the tradition of the medieval schoolmen that, it is argued, arises from the synthesis of biblical revelation (mediated by the Christian tradition) with Greek thought. It will be described how scholasticism proceeds in its essence from a view of God as single subject giving rise to a dilemma arising from the contradictory positions to which rival scholastic views of God lead.

In response to equally unacceptable alternatives arising from the rival scholastic positions, the trinitarian vision will be outlined as it can be found in the thought of Kuyper and Van Til and arguably implicit in the work of Calvin. It will be indicated how Kuyper and Van Til perceive the need to base one's understanding of the world on one's belief in God as Trinity, and how this provides a genuine alternative to the two views of the relation of God to the world, found in scholasticism and a sounder basis for Christian thought and action.

\section{Scholasticism and the Euthyphro dilemma}

This section seeks first to describe what is meant in this article by 'scholasticism', and then describes the classical dilemma which presages the later contradictions at the heart of the scholastic enterprise. 


\section{What is scholasticism?}

'Scholasticism' in this article is used in a polemical-critical sense to denote the influence from earliest times of Greek thought upon Christian thinkers as they attempted to present a coherent and intellectually credible Christian account of God and the world. In so doing, it is argued that Christian thought was seriously compromised in the categories it used to analyse and describe both God and the world. This critical-polemical use of the term scholastic needs to be distinguished from the strictly historical-sociological use to characterise the academic practice of the medieval university schools rather than the theological reflection of the monasteries (Muller 2003:1.360-405, 4.391-403). That neutral, historical-sociological sense of 'scholasticism' usage does not necessarily exclude its critical-polemical sense employed here.

The basic scholastic method uses the procedures of genus proximum and differentia specifica to form concepts by a process of abstraction. This process of abstraction allows a kind of entity to be identified by its 'properties' - attributes common to all entities of that kind (genus proximum). Through this process, the entity can be described with ever greater exactitude (differentia specifica). In this way, one finds concepts that correspond to the reality of the thing so designated - the process of adequatio intellectus et rei (Strauss 2009:25, 347).

The term scholasticism here covers both 'realism' in its strong and moderate forms, and 'nominalism'. These positions were variously represented in medieval philosophy realism in the 'antique way' (via antiqua) and nominalism in the 'modern way' (via moderna) (Hoenen 2003:13-22). Scholasticism in its various strands accords universals a hypostasised existence, albeit in different ways: in 'strong realism' the universals are held to exist eternally prior to the experience of particulars ante rem; in moderate realism the universals are held to be instantiated in particulars (in re); while in the nominalism of the via moderna, the properties of particulars are held to be purely creations of the mind which are then, by convention, attached to particulars as they are experienced (post rem) (Dooyeweerd 1935b:2.317318; 1997:2.386-387; see Ive 2012:99-103 for a extended critique).

While there is not a direct correspondence between the different epistemologies just described and what will be characterised as the 'intellectualist' and 'voluntarist' approaches, the scholastic method of the adequatio provides the epistemological framework within which the scholastic dilemma in the account of the relation of God and the world is given - not least the notion that God is a being (or Being) to whom properties attach either directly or by attribution.

\section{The Euthyphro dilemma}

It will be the argument in this article that scholasticism in its different forms gives rise to a dilemma which is not capable of resolution within the scholastic problematic.
The dilemma arises from the problem articulated most famously by Plato (428/427-348/347 вСЕ) in his Euthyphro dialogue: 'Is the pious being loved by the gods because it is pious, or is it pious because it is being loved by the gods?' (10a in Plato 1997:9). This problematic can be extended to the more general question: Does God command the good because it is good, or is it good because God commands it?

As we shall see in the following section, the 'intellectualist' approach involves the affirmation of the first half of the statement, while the 'voluntarist' approach involves the affirmation of the latter half.

\section{The intellectualist versus voluntarist dilemma within scholasticism}

In this section, the 'intellectualist' and the 'voluntarist' approaches and the dilemma in scholasticism to which they respectively give rise against the wider backdrop of the difficulties in the scholastic problematic will be described.

\section{The intellectualist approach}

The intellectualist approach starts with the idea of God as a supreme mind that gives the universe its character. Here we see the influence, albeit in different ways, of the philosophical thinking of both Plato (already mentioned) and Aristotle (384-322 все), the two pre-eminent philosophers of the ancient Greek world (Shults 2005:42). The reformational philosopher, Dirk Vollenhoven, sees the influence of Galen (120-c.200/216) and Alexander of Aphrodisias (born 200 BCE) who equated the divine Logos with the universal intellect found in the final conception of Aristotle's Metaphysics (Vollenhoven 1992:60-61). An intellectualist scholasticism can also be discerned in the $M u^{\prime}$ tazilite tradition in Islam following Wasil ibn 'Ata' (700-748 вCE) and those Islamic theologians influenced by both Aristotle and the neoPlatonists (Fakhry 2005:45-65).

Within Christian thought, an intellectualist approach is evident in Boethius (c.480-c.525), who played a critical role in shaping the scholastic tradition. Boethius (De persona et duabus naturis, Ch. 3.2) famously defined a person as a 'rational substance'. Boethius was influenced heavily by Neoplatonic and Stoic influences transmitted especially through Augustine (Shults 2005:45). In terms of the intellectualist approach, God as the supreme person, is thus seen as the perfection of intellect or, as Boethius (Consolation of Philosophy 142, quoted in Shults 2005:42) puts it, 'understanding alone is the property of the divine'. Boethius holds that in theology we need to proceed according to the mode of the intellect as the study of God's substance which is 'without matter and motion'. He contrasts this to mathematics concerned with bodies with matter, and the natural sciences concerned with bodies with matter and motion (Aertsen 1996:116, quoting De Trinitate c.2). Moreover, for Boethius God cannot act except in accordance with his substance, that is to say, pure reason. 
The intellectualist approach can be seen developed especially in the thinking of Thomas Aquinas (1225-1274) (Vollenhoven 2005:69). Aquinas's position is a 'moderate realist' one, because for him the universal forms only become operative once they are individuated (in re) by matter. The interpretation of Aquinas is a vexed question subject to a variety of different views - not least about the nature of analogy itself. On the one hand, there is the interpretation led by Cardinal Tommaso de Vio Gaetani Cajetan (1469-1534) seeing the analogy in proportional terms, linked externally and formally. On the other hand, there is the reading of Francisco Suárez (15481617) where the analogy is seen as being constituted by the intrinsic communication of attributes. However, even from a Cajetanist reading, it can be suggested that through the analogia entis, Aquinas argues for a certain (but qualified) continuity between the (ultimate) Being of God and the (derived) being of the world [author's emphasis] (Klubertanz 2009:138-140; Montagnes 2004:13-15). For Aquinas, the being of the world is suspended from God's being, and in the process of redemption, one's mind is drawn to participate in the mind of God (Gunton 1998:99-102; Shults 2005:45-46; Smith 2004:156-166).

According to John Milbank, a modern age exponent and reinterpreter of the intellectualist position, we can have 'participation in the mind of God' according to a certain kind of cognitive 'illumination' through reason and revelation the latter being a heightened form of the former (Davies, Janz \& Sedmak 2007:110, 112, n.131; Milbank 1999:24). Here the distinction between ratio (pertaining to the world of sense experience) and intellectus (pertaining to the unchanging world of pure contemplation) comes into play. Turner (2004:80-88) argues that distinction between intellectus and ratio (inherited from Augustine) points towards an understanding of God as at once transcendent of the world and yet engaged with it. This interplay unifies and resolves the diversity so discovered, culminating in the contemplation of Being itself together with the other 'transcendentals' (as they were later called) of scholastic philosophy: the One, the True, the Good, and the Beautiful (the last, the 'forgotten transcendental') (see Aertsen 1996:159-354 et seq.; Gilson 1963:149-178).

The intellectualist position sees all things to be ordered through the eternal law (lex aeterna), and God is then seen as working in the world primarily through secondary causes (Dooyeweerd 1923:9-10, 13). The eternal law, which springs directly from the mind of God, is reflected in natural law (lex naturalis). The latter can be known by human mind as a reflection of divine reason (Dooyeweerd 1935a:356-357; 1935b:1.145-147; 1997:1.182-185). The divine nature is both the principle of all things, the being from which all being derives as well as that which subsists in itself and can only be made known by divine revelation. God is seen as the highest intelligible, free from matter and truly universal (Dooyeweerd 2013:274-275).

This is not to say that there is not a reaching out to a trinitarian approach during the medieval period. Aquinas argues that the knowledge of the divine Persons is necessary for correct thinking about God as creator of the world, because to say that God produced all things by his word, the procession of love excludes the possibility that he produced things by necessity (Aquinas 1911:1.32.1.3). However, the dichotomy in Aquinas' thought between grace and nature (or between revelation and reason) does not allow him to work this out fully. For Aquinas, the Trinity is a category of faith rather than reason, and so supplements what can be known by natural reason (Aertsen 1996:120, 122, 124-125 quoted from In Boeth. De trin. Q. 1.4, sed contra: 'Deus esse trinum et unum est articulus fidei').

What thus characterises the intellectualist approach with all its qualifications is the view of God as the summit and epitome of reason, and thus the basis for ordering of the world is as good and rationally apprehensible.

\section{The voluntarist approach}

Unlike the intellectualist approach, the voluntarist approach rejects any attempt to deduce the character of God from the character of the world or vice-versa and instead stresses the discontinuity between God and the world. In the voluntarist approach, God is seen primarily as the one who exercises sheer will and things are as they are simply because God so decrees. From a voluntarist point of view, God is entirely unknowable and arbitrary. This approach can be identified in both Epicurean and Stoic philosophy (Shults 2005:43). This can also be seen in the Islamic tradition which followed $\mathrm{Abu}$ al-Hasan al-Ash'ari (873-935) and which is now dominant in Sunni Islam (Fakhry 2005:215-224).

In Christian medieval scholastic thought, it was chiefly through Duns Scotus (1265/66-1308) (Vollenhoven 2005:69) and William of Ockham (1300-1349) that the voluntarist approach came to prominence. For Scotus, the attributes of both divine and created being are real as such and not a matter of convention. He emphasised the will of God (see Gunton 1998:117-125; Ross \& Bates 2003; Shults 2005:146). Ockham, who questioned the intrinsic reality of any universal properties, emphasised the absolute power of God (potentia/ potestas absoluta) - unconstrained by the divine ordering of the world (potentia/potestas ordinata) (Dooyeweerd 1923:6364; 1935b:358-361; 1997:1.185-188; Shults 2005:44-47; Strauss 2009:548). What Scotus and Ockham nevertheless have in common is a view of God's engagement with the world characterised by commands rather than one involving the upholding of universal laws.

While the intellectualist view holds that the being of the world is linked with that of God (even if the 'Being', duly capitalised, of God is only analogically related to the being of the world, the voluntarist view denies this. From the voluntarist perspective, all being is 'univocal', that is it presents itself to us on its own terms not by virtue of its dependence on something else (Smith 2004:88-89, 93, 96-100). God takes on by an act of will those attributes that he chooses to assume, having first created those attributes by sheer fiat. 
The reformational philosopher, Roy Clouser himself seems to hold what is called here the 'voluntarist' position. Clouser qualifies his position with the caution that the term will itself is an anthropomorphic term which should not be identified with the 'originating unknowable being of God'. Instead, he refers to God's 'unconditional being' (Clouser 2005:361, n. 318). However, this only succeeds in replacing a personal description of God with an impersonal one.

\section{Difficulties with the scholastic problematic}

Scholasticism, whether in its intellectualist or voluntarist forms, presents us with a certain problematic. Shults (2005:41-65; see Dooyeweerd 1935b:475; 1997:1.509) has pointed out the difficulty that arises because of the conception of God as a single subject - as a single point of action, and either as a single intellect (as in the intellectualist view) or as a single will (as in the voluntarist view). The problem then arises of how to explain the relationship between God and the world.

The intellectualist and the voluntarist approaches portray the relationship between God and the world in terms of conjunction or disjunction respectively: either the world is seen as an extension of God's being or God is seen as entirely separate from the world. The former conception (often called 'panentheism' to distinguish it from 'pantheism' - an outright identification of the world with God), tends to accord divine status to elements of the world and compromises God's aseity, that is, God's self-existence (Shults 2005:132; Vollenhoven 1938:74). Seeing the relationship of God and the world as a disjunction does not help either. Disjunction is no less a mechanism that brings entities into comparative relation than is conjunction; only, that disjunctive relation is arbitrary and extrinsic rather than law-governed and intrinsic (Davies et al. 2007:106-107).

There are also difficulties with the Augustinian-Thomist notion of the timeless universals. On one hand, it undercuts the sole eternity of God because there are eternals alongside God, albeit created by him. The reformational philosophical tradition is not free of this: Abraham Kuyper had residual elements of strong realism in this thought. Indeed, the scholastic notion of the aevum, a created eternity which the reformational philosopher Herman Dooyeweerd himself briefly adopted at one point in his development, may be questioned on these grounds (Ive 2012:34, n.103: 65, n. 140). On the other hand, paradoxically, the idea of God's eternal act of creation undercuts the idea of God's involvement in time and lays the foundations for deism. It also tends to see history as the playing out of what has already been decided from eternity, or as the interplay of pre-determined elements (Gunton 1998:79-102).

The notion of divine simplicity, as developed by Anselm and Aquinas, is designed to get around the problem that the attributes of God might be thought of as existing independently of God and so compromises God's aseity. The 'solution' it offers is to say that God does not possess his attributes, but rather that God is, in himself, the sum of all the highest attributes as the supreme perfection of them. This reduces any discussion of God to complete unintelligibility because if all the attributes of God are to be identified with God himself, this means that they therefore must be identified with one another. Thus, God's attributes lose any distinct meaning and the account is in danger of becoming unintelligible (Clouser 2005:202-207).

Within the scholastic problematic, God is thus seen either as subject to the laws which govern creation as in the intellectualist approach, or in terms of the voluntarist approach, is seen as arbitrary. Scholastic philosophy therefore falls into a dilemma, prefigured as we have seen, in Plato's Euthyphro dialogue. On the one hand, there is the intellectualist position which sees God as subject to eternal universals. On the other hand, there is the voluntarist position which sees God as an agency in contingent relationship with the world. In terms of both the intellectualist and voluntarist positions, the relationship between God and the world is seen in correlative terms. In the intellectualist position this correlation is expressed in terms of continuity, albeit classically in terms of the analogical continuity between God and the world. In the voluntarist position, this is expressed in terms of the discontinuity between God and the world.

\section{The covenantal trinitarian alternative in Calvin, Kuyper and Van Til}

Scholasticism thus leaves us with the question: How is it possible both to understand God as free and transcendent and the same time as knowable and not arbitrary? This is not just a theoretical question, but goes to the roots of who we are as human beings, seeking a purposive basis for our lives within the God-given world order.

Next, three reformed thinkers who together can help to provide a radical alternative to the scholastic problematic.

\section{Calvin's programmatic rejection of the scholastic problematic}

John Calvin (1509-1564) who gave reformed theology his name, marks a radical break with the scholastic problematic. God is, as Calvin $(1961: 10.13,179)$ puts it, both free from law (legibus solutus) but not arbitrary (non exlex). Dooyeweerd points out that Calvin's dictum decisively breaks with the antithesis between realism (in both its scholastic forms) and nominalism. Calvin equally rejects the intellectualism of Thomas Aquinas and the notion of the absolute power of God (potestas Dei absoluta - William of Ockham) of which the latter ranked above the divine ordering of the world (potestas Dei ordinata) (Calvin 1960:3.23.2).

Calvin (1960:1.13.2) argues that it is meaningless to speak of a divine reality 'beyond' God's triune self-revelation as he writes, 'Unless we grasp these [i.e. the Persons as self- 
revealed], only the bare and empty name of God flits about in our brains, to the exclusion of the true God.' When we speak of God as Trinity we are responding to God's self-revelation supremely and definitively in the person of Jesus of Nazareth, and his incarnation, death, resurrection and ascension (Torrance 2001:10-12, 15).

The constitution of the world is not arbitrary or ad hoc. Rather, it is consistent with the covenant settled eternally between the three Persons. Peter Lillback (2001:212-214; see Gaffin 2006; Shults 2005) describes how this inner-triune relationship, this 'self-binding' is worked out for Calvin in history by the Holy Spirit in the lives of believers, bringing them into union with Christ. Indeed, it is this trinitarian relationship which is the basis on which the break with both intellectualism and voluntarism can be made.

On the one hand according to Calvin, God is free of the law, because laws result from the mutual compact of the three Persons acting out of freedom and love, and not out of submission to any external or impersonal law or principle. On the other hand, God is not arbitrary, because the mutual love of the Father, Son and Spirit gives the universe both stability and settled character.

Shults (2005) describes how scholasticism attempts to present a notion of God's infinity exclusive of the created order. However, the biblical picture of God speaks rather of God who 'fills the earth itself', whose infinity is not set against creation but revealed in it. As Shults (2005:22-40, 97-132) points out, God's infinity should not be contrasted 'extensively' as marking out a boundary between God and creation, but should properly be understood 'intensively' as comprehending creation within the all-surpassing liveliness of God's action. He (Shults 2005:107) argues that Calvin, among others, held to such an 'intensive' understanding of God's infinity.

\section{Kuyper's contribution}

Following on from Calvin, a powerful statement of the trinitarian approach can be found in the writings and lectures of the great Calvinist theologian and statesman, Abraham Kuyper (1837-1920). Kuyper himself is not entirely free from scholastic influences and is not always consistent in the way he develops his systematic thinking. Van Til (1974:34-44) finds in Kuyper a pronounced tendency to intellectualism with an emphasis on the primacy of logically defined universals over the individual and material. However, by building his thinking on a trinitarian foundation, Kuyper lays the basis for moving beyond the scholastic dilemma with a radically new start. In doing so, he draws on a well-developed covenantal trinitarian tradition within reformed theology (Smith 2002:73-77; 2003:15-31).

For Kuyper, the Persons of the Trinity bind themselves in a covenant for the existence and wellbeing of the world, and there is constancy in their governance of the world that comes out of their compact with one another. The covenant expresses their mutual, free and loving interdependence. All things hold together just as the Persons of the Trinity are in mutual interrelation. The work of creation and redemption both find their highest unity in Christ. As the eternal Son, $\mathrm{He}$ participates in the work of both, not as a foreign element, but as a full co-director of the 'Eternal Counsel of Peace' (eeuwigen Vrederaad), and as mediator of both creation and redemption (Bratt 1998:182-187; Kuyper 1903:642-649; 1904:1.9.4, 202209; 1911: §5, 80-90 [esp. p. 89]; 1925: ch. 47, 289-291, ch. 56, $347-349$, ch. $68,417-419$; ch. $83,507-509$ ).

\section{Van Til's contribution}

Kuyper's insights were developed further by the Dutch American Calvinist philosopher, Cornelius van Til (18951987). Van Til argues that the Trinity is the sole basis for understanding the unity and plurality of the world. The claim about the pluralistic nature of created reality cannot come from the mere consideration of 'brute facts', because for Van Til, these do not exist as all experience is subject to one's interpretation. This rests implicitly on a pre-theoretical vision, or as Van Til puts is, a 'presupposition'; more specifically, a presupposing about the equal ultimacy of unity and diversity which can only be founded on the prior belief in unity and diversity of the Trinity (Van Til 1997a:35-40).

Van Til argues that to know God as Father, Son and Holy Spirit does not mean that these relationships come into being after the act of creation. God authoritatively reveals his own nature and constitution to us insofar as we can know anything of him at all. Instead of setting the revelation of God against God's self-revelation in the world, Van Til contends that God's self-revelation is explicitly or implicitly the basis for one's understanding of the world (Van Til 1997a:10.2 where he draws on Bavinck 1918).

God as Trinity is unity in diversity. God does not need to create the world in order to express his diversity. He exists prior to and apart from creation in the mutual and complete relationships between the eternal Persons (Van Til 1997a:10. 2). That the Christian faith describes God as 'Father', 'Son' and 'Holy Spirit', in other words using figures of speech derived from creation ('father', 'son', 'wind' or 'breath'), does not mean that these relationships come into being after the act of creation. Rather, these created forms of expression are the means by which God authoritatively tells us how we are to speak of him. As Van Til (1997b) puts it:

The immanent relations within the three persons of the holy trinity are the foundation of the relations whereby the triune God sustains to the world [sic]. It is, of course, true that we know nothing about the immanent relations within the Persons of the trinity except through the revelation of this trinity through Christ in the Scriptures. But since God himself has told us that he is triune in his being, it is this triune being that lies at the foundation of creation and redemption. (ch. 3.1)

Tipton (2004:114-142) characterises Van Til's position as setting out the 'representational principle': inwardly 
('immanently') in the relations of love between the three Persons and outwardly ('economically') in the covenant arising from these relations according to which the world is created and redeemed. For Van Til, the covenant asserts the principle of personality at the heart of the universe and places humanity in a person-to-person relationship with God (Frame 1995:59-60)

\section{Some implications of the covenantal trinitarian approach}

Thus, the key trinitarian insight such as developed by Kuyper and Van Til following Calvin, is that only the inner-triune relations bind the Persons and not anything external to God. Accordingly, from a trinitarian perspective, God is not seen as subject to the order of the world, although he reveals himself to us sovereignly and definitively in the language of the created order. At the same time, the notion of a discontinuity between the sovereignty of God and the order of the world is also rejected. Rather, the order of the world is determined sovereignly by the Persons acting together in a self-binding covenant among them.

In a trinitarian conception, each Person of the Trinity is immediately and distinctively engaged with the world in creation, redemption and in the bringing of all things to their final glory in a way consistent with their relations to one another. The world is not related to God as an entity over against God, but is the result of the joint action by the three Persons. A trinitarian approach can thus affirm both God's involvement in the world and his transcendence of it without reducing God to the world, or seeing God as entirely detached from it. It allows us to understand the world as subject to God's law without implying thereby that God himself is subject to that law.

From a trinitarian perspective, the character of the world thus reflects the character of God, but the world is neither necessary nor contingent to God' existence. Indeed, God's existence cannot be categorised in terms of either necessity or contingency. The world is not to be seen as an extension of God, because God does not depend on the world in any way - even as creator. The Persons are fully self-contained in their relations with one another; the world is created freely and not out of necessity. But God is genuinely engaged in the world through the universal action of the Holy Spirit and the embodiment of the Son. The order of the world is constituted by the free covenantal love of the Persons of the Trinity for one another and revealed in the sovereign engagement of all three Persons jointly in the world.

The implications for church and society of the covenantal trinitarian vision are far-reaching. The church, universal as the radical expression of Christian commitment, needs to be seen as the outflowing of the creative, redemptive and transforming love shared by Father, Son and Holy Spirit. Christian vocation needs to be seen as the forming and exercise of right relationships in response to God's call. God as Trinity calls humanity in the depth dimension of its existence (the 'heart' as understood in biblical terms) into the exercise of right relationships according to the law of love (Ive 2012:45, 119-149; Strauss 1969:108-109). This contrasts with practical implications of the respective scholastic approaches, and even a residual scholasticism in Kuper himself (Strauss 1969:103), as the redemption achieved by Christ needs to be seen as applicable to the whole of creation and to all social entities, not merely the church as institution:

- On the one hand, social entities should not be seen as being constituted by an appeal to a rational order or to natural law. The creation order should not be seen as a quasi-entity in its own right as in the scholastic notion of a natural law, but rather is the outcome of the joint activity of the three Persons sustained moment by moment by God's creative and providential power. All things point to an Origin beyond themselves, rather than being seen as self-contained, quasi-divine 'substances' (Ive 2012:185-191).

- On the other hand, the legitimacy of social entities does not rest either in the fiat of a central authority, as somehow the conduit of God's will, nor alternatively, on the collective will of its membership. Rather, all entities have as their foundation the eternal covenant flowing from the love among the Three Persons which is the basis for the harmony among the harmony in diversity of all the aspects of creation (Ive 2012:191-195).

The church as institution (one of the many expressions of the universal church as the body of all believers) is a web of relationships within which this love is proclaimed and identified through the distinctive office of the preaching of God's self-revelation as found in the Bible, and the correct administration of the sacraments of baptism and the Lord's Supper. It is not a link in a hierarchy of being, and on the other hand, not merely a club or social association, but rather the authoritative bearer of the word of apostles as the primary witnesses to the death, resurrection and ascension of Jesus - the one, true Israelite, fully human and fully divine, fulfilling the covenantal promise within the triune co-inherence. These relationships of word and sacrament, embodying the triune love, mark out the church as institution, as it is true to its calling to share the Good News of Jesus and to equip its members to be salt and light within society as a whole to be able in their different callings to address all aspects of creation (Strauss 1969:111, 114)

\section{Conclusion}

What has been presented is necessarily a sketch rather than an exhaustive presentation of the positions of the thinkers mentioned to whom it cannot do justice. The argument has focussed on the central scholastic problematic which gives rise to the central dilemma: that God is either seen as supreme intellect or supreme will. What intellectualism and voluntarism, the rival scholastic conceptions, present as alternatives are really rival errors, each giving rise to specific problems. 
By contrast a robust covenantal understanding of God as Trinity allows us to conceive of God as at once faithful in his dealing with the world, and yet not dependent on the world for his existence. We see this enunciated powerfully in the thought of Abraham Kuyper and Cornelius van Til, and indeed, implicitly in the thinking of John Calvin himself. Only the love, revealed in the mutual and self-giving love of Father, Son and Holy Spirit, can truly be the basis for a satisfactory view not only of God, but indeed of the world. This is the world which the triune God has created, has redeemed through Christ, and is, through the Holy Spirit, in the process of bringing to its final glory in the diversity of situations and social expressions within which God's people are called and exercise their service.

\section{Acknowledgements}

The author would like to thank Stephen Bishop for his help in preparing this article, as well as his two sons, Edward and Robert. The author would like to express his indebtedness to Ralph Allen Smith to his key insights about the role of both Abraham Kuyper and Cornelius van Til in developing the covenantal trinitarian vision. However, the development of the context and wider implications of these insights is the authors own. The author would also like to add that while identifying with the 'reformational' philosophical tradition of Abraham Kuyper and his later followers, any critique of Kuyper or others is not a criticism of the tradition as such, but is offered from within the tradition in the spirit of semper reformanda.

\section{Competing interests}

The author declares that he has no financial or personal relationships which may have inappropriately influenced him in writing this article.

\section{References}

Aertsen, J.A., 1996, Medieval philosophy and the transcendentals, E.J. Brill, Leiden.

Aquinas, T., 1911, Summa theologica, transl. Fathers of the English Dominican Province, AGES Software, Albany, VA. (Master Christian Library 6.0).

Bavinck, H., 1918, Gereformeerde dogmatiek, J.H. Kok, Kampen.

Bratt, J.D. (ed.), 1998, Abraham Kuyper: A centennial reader, W.B. Eerdmans/ Paternoster Press, Grand Rapids, MI.

Calvin, J., 1960, Institutes of the Christian religion, 2 vols., transl. F.L. Battles, Library of Christian Classics, The Westminster Press, Philadelphia, PA.

Calvin, J., 1961, Concerning the eternal predestination of God, James Clarke \& Co. Ltd London.

Clouser, R.A., 2005, The myth of religious neutrality: An essay on the hidden role of religious beliefs in theories, 2nd edn., University of Notre Dame Press, Notre Dame.

Davies, O., Janz, P. \& Sedmak, C., 2007, Transformation theology: Church in the world, T\&T Clark, London.

Dooyeweerd, H., 1923, 'Roomsch-katholiek en anti-revolutionaire staatkunde', in Advizen en Studies, Kuyperstigting, The Hague.

Dooyeweerd, H., 1935a, 'De wetsbeschouwing in Brunner's boek Das Gebot und die ordnungen', A.R. Staatkunde 9, 334-374.

Dooyeweerd, H., 1935b, De wijsbegeerte der wetsidee, H.J. Paris, Amsterdam.

Dooyeweerd, H., 1997, A new critique of theoretical thought, 4 vols., Presbyterian \& Reformed/Edwin Mellen Press, Lewiston.

Dooyeweerd, H., 2013, Reformation and scholasticism in philosophy, vol II philosophy of the cosmonomic ided and the scholastic tradition in Christian thought, transl.
M. Verbrugge, eds. D. Strauss, L. Boliek, R. Vunderink \& H. Van Dyke, Paideia Press, Grand Rapids, MI.

Fakhry, M., 2005, A history of Islamic philosophy, 3rd edn. Columbia University Press, New York.

Frame, J.M., 1995, Cornelius van Til: An analysis of his thought, P\&R Publications, Phillipsburg, NJ.

Gaffin, R.B., 2006, 'Union with Christ: Some biblical and theological reflections', in A.T.B. McGowan (ed.), Always reforming: Explorations in systematic theology, pp. 271-189, InterVarsity Press, Leicester.

Gilson, E., 1963, Elements of a Christian philosophy, Mentor-Omega, New American Library of World Literature, Inc., New York, NY.

Gunton, C., 1998, The triune creator: A historical and systematic survey, Edinburgh University Press, Edinburgh.

Hoenen, J.F.M., 2003, 'Via antiqua and via moderna in the fifteenth century: Doctrinal, institutional and church political factors in the Wegestreit', in R.L. Friedman \& L.O. Nielsen (eds.), The medieval heritage in early modern modern metaphysics and modal theory, 1400-1700, pp. 9-36, Kluwer Academic Publishers, Dordrecht.

Ive, J.G.A., 2012, 'A critically comparative Kuyperian analysis and a trinitarian, 'perichoretic' reconstruction of the reformational philosophies of Dirk H.Th Vollenhoven and Herman Dooyeweerd', PhD thesis, King's College London.

Klubertanz, G.P., 2009, St Thomas Aquinas on analogy: A textual analysis and systematic synthesis, Wipf \& Stock, Eugene, OR.

Kuyper, A., 1903, De gemeene gratie. Tweede deel. Het leerstelling gedeelte, Hoveker \& Wormser, Amsterdam.

Kuyper, A., 1904, E voto dordraceno:toelichting op den Heidelbergschen catechismus, 4 vols., J.H. Kok, Kampen.

Kuyper, A., 1911, Dictaten dogmatiek. III. Locus de providentia, peccato, foedere, Christo, college-dictaat van een der studenten, J.H. Kok, Kampen.

Kuyper, A., 1925, To be near unto God, transl. J.H. de Vries, Wm B. Eerdmans Grand Rapids, MI.

Lillback, P.A., 2001, The binding of God: Calvin's role in the development of covenant theology, Paternoster/Baker Academic, Grand Rapids, MI.

Milbank, J., 1999, 'The theological critique of philosophy', in J. Milbank, C. Pickstock \& G. Ward (eds.), Radical orthodoxy, pp. 21-37, Routledge, London.

Montagnes, B., 2004, The doctrine of the analogy of being according to Thomas Aquinas, rev. edn., Marquette University Press, Milwaukee, Wisconsin. (Marquette Studies in Philosophy).

Muller, R.A., 2003, Post-reformation reformed dogmatics, Baker Academic, Grand Rapids, MI.

Plato, 1997, Complete works, ed. J.M. Cooper, Hackett Publishing Company, Indianapolis, IN.

Ross, J.F. \& Bates, T., 2003, 'Duns Scotus on natural theology', in T. Williams (ed.), The Cambridge companion to Duns Scotus, pp. 193-237, Cambridge University Press, Cambridge.

Shults, F.L., 2005, Reforming the doctrine of God, Eerdmans, Grand Rapids, MI.

Smith, J.K.A., 2004, Introducing radical orthodoxy: Mapping a post-secular theology, Baker Academic, Grand Rapids, MI.

Smith, R.A., 2002, Paradox and truth: Rethinking Van Til by comparing Van Til, Plantinga and Kuyper, Canon Press, Moscow, ID.

Smith, R.A., 2003, The eternal covenant: How the trinity reshapes covenant Theology, Canon Press, Moscow, ID.

Strauss, D.F.M., 1969, 'Skolastiek en gereformeerde skolastiek kontra reformatoriesChristelike denke', Nederduitse Gereformeerde Teologiese Tydskrif 10(2), 97-114.

Strauss, D.F.M., 2009, Philosophy as the discipline of disciplines, Paideia Press, Grand Rapids, MI.

Tipton, L.G., 2004, 'The triune personal God: Trinitarian theology in the thought of Cornelius Van Til', PhD thesis, Westminster Theological Seminary, Philadelphia, PA.

Torrance, T.F., 2001, The Christian Doctrine of God: One Being Three Persons, T\&T Clark, Edinburgh and New York.

Turner, D., 2004, Faith, reason, and the existence of God, Cambridge University Press, Cambridge.

Van Til, C., 1974, Common grace and the gospel, Presbyterian and Reformed Publishing Company, Nutley, NJ.

Van Til, C., 1997a, 'Christianity and Barthianism (1962 H)', in E.H. Sigward (ed.), The works of Cornelius Van Til, 1895-1987, Labels Army Company, New York, NY.

Van Til, C., 1997b, 'The theology of James Daane (1959)', in E.H. Sigward (ed.), The works of Cornelius Van Til, 1895-1987, Labels Army Company, New York, NY.

Vollenhoven, D.H.Th., 1938, 'Realisme en nominalisme (38v)', Philosophia Reformata 3, 65-83, 150-165.

Vollenhoven, D.H.Th., 1992, 'Norm en natuurwet (51h)', in A. Tol \& K.A. Bril (eds.) Vollenhoven als wijsgeer: Inleidingen en teksten, pp. 55-64, Buijten \& Schipperheijn, Amsterdam.

Vollenhoven, D.H.Th., 2005, 'Short survey of the history of philosophy (56b)', in K.A. Bril (ed.), D.H.Th. Vollenhoven. The problem-historical method and the history of philosophy, pp. 21-88, De Zaak Haes, Amstelveen. 